University of Nebraska - Lincoln

DigitalCommons@University of Nebraska - Lincoln

2012

\title{
Beef Quality of Calf-Fed Steers Finished on Varying Levels of Corn-Based Wet Distillers Grains Plus Solubles
}

\author{
A. S. Mello Jr. \\ University of Nebraska-Lincoln \\ C.R. Calkins \\ University of Nebraska-Lincoln, ccalkins1@unl.edu \\ B. E. Jenschke \\ University of Nebraska-Lincoln \\ Timothy . P. Carr \\ University of Nebraska-Lincoln, tcarr2@unl.edu \\ M.E.R. Dugan \\ Agriculture and Agri-Food Canada \\ See next page for additional authors
}

Follow this and additional works at: https://digitalcommons.unl.edu/animalscifacpub

Part of the Animal Sciences Commons

Mello, A. S. Jr.; Calkins, C.R.; Jenschke, B. E.; Carr, Timothy . P.; Dugan, M.E.R.; and Erickson, G. E., "Beef Quality of Calf-Fed Steers Finished on Varying Levels of Corn-Based Wet Distillers Grains Plus Solubles" (2012). Faculty Papers and Publications in Animal Science. 783.

https://digitalcommons.unl.edu/animalscifacpub/783

This Article is brought to you for free and open access by the Animal Science Department at DigitalCommons@University of Nebraska - Lincoln. It has been accepted for inclusion in Faculty Papers and Publications in Animal Science by an authorized administrator of DigitalCommons@University of Nebraska - Lincoln. 


\section{Authors}

A. S. Mello Jr., C.R. Calkins, B. E. Jenschke, Timothy . P. Carr, M.E.R. Dugan, and G. E. Erickson 


\section{JOURNAL OF ANIMAL SCIENCE}

The Premier Journal and Leading Source of New Knowledge and Perspective in Animal Science

\section{Beef Quality of Calf-Fed Steers Finished on Varying Levels of Corn-Based Wet} Distillers Grains Plus Solubles

A.S. Mello, Jr., C.R. Calkins, B.E. Jenschke, T.P. Carr, M.E.R. Dugan and G.E. Erickson

J ANIM SCI published online August 2, 2012

The online version of this article, along with updated information and services, is located on the World Wide Web at:

http://jas.fass.org/content/early/2012/08/01/jas.2010-3239 
Running Head: Feeding wet distillers grains plus solubles.

\section{BeEF QuAlity of CALF-FEd SteERs Finished ON VARYING LEVELS OF CORN-BASED WeT DistilleRs GRAINS PluS SOLUBLES ${ }^{1,2}$.}

A.S. Mello, Jr. ${ }^{*}$, C.R. Calkins ${ }^{*}{ }^{4}$, B.E. Jenschke*, T.P. Carr ${ }^{\dagger}$, M. E. R. Dugan ${ }^{\ddagger}$, and G.E. Erickson*

*University of Nebraska, Department of Animal Science and ${ }^{\dagger}$ Department of Nutrition and Health Sciences, Lincoln, NE 68583-0908. ${ }^{\ddagger}$ Agriculture and Agri-Food Canada, Lacombe, Canada.

\footnotetext{
${ }^{1}$ A contribution of the University of Nebraska Agricultural Research Division

${ }^{2}$ This project was funded in part by the Beef Checkoff.

${ }^{3}$ CAPES / Fulbright - Brazil.

${ }^{4}$ Corresponding author: ccalkins1@unl.edu
} 


\section{ABSTRACT}

Ninety-four, calf-fed crossbred steers were randomly allocated to three different dietary treatments $(0 \%, 15 \%$ or $30 \%$ wet distillers grains plus solubles - WDGS - DM basis) and fed for $167 \mathrm{~d}$ to test the influence of different levels of WDGS on quality attributes of beef. At $48 \mathrm{~h}$ postmortem, marbling score, marbling texture, and marbling distribution were assessed by a USDA grader. After grading, one ribeye slice (Longissimus thoracis) about $7 \mathrm{~mm}$ thick was excised from each carcass, trimmed of subcutaneous fat, and analyzed for fatty acid profile and lipid content. At $7 \mathrm{~d}$ postmortem, 48 top blades (Infraspinatus), strip loins (Longissimus lumborum) and tenderloins (Poas major) (16 per treatment) were removed from shoulder clods and short loins and two steaks were obtained for measurement of mineral content, fatty acid profile (except strip loins), trained sensory analysis, objective color and lipid oxidation. Finishing diet did not influence the content of total lipid $(P=0.19)$ or marbling, marbling texture, or marbling distribution ( $P=0.46, P=0.84$ and $P=0.40$, respectively). Feeding WDGS created a linear increase $(P<0.01)$ of PUFA in all three muscles (Longissimus thoracis showed: 4.90, 5.91, and $6.23 \%$ for 0, 15 and 30\%, respectively). Similar responses were observed for 18:2(n-6) and total omega 6 fatty acids. Conversely, lower proportions of 18:1(n-7) fatty acid were observed in beef from animals fed 30\% WDGS $(P<0.01)$. Total trans fatty acids increased linearly in strip loin and top blade steaks $(P<0.01)$ whereas proportions of 16:0 and 14:1(n-5) fatty acids decreased in all muscles $(P<0.01)$ as levels of WDGS increased. Diet did not affect mineral content of top blades or strip loins. For tenderloin steaks, sulfur concentration was lower when 30\% of WDGS was fed $(P=$ 0.05). No effects on sensory attributes and Warner Bratzler shear force were observed ( $P$ $\geq 0.50$ ), except a minimal effect on strip loin juiciness (5.32, 4.86, and 5.52 for 0,15 , and 
$30 \%$, respectively; $P=0.02$ ). Top blade and tenderloin steaks from cattle fed $30 \%$ WDGS were significantly less red (lower a* values) on day 3 of simulated retail display $(P<0.04)$. Inclusion of $30 \%$ WDGS in the diet resulted in higher levels of oxidation after $7 \mathrm{~d}$ of retail display for top blade and strip loin steaks $(P<0.01)$. Feeding WDGS to calf-fed steers altered fatty acid profile, increased oxidation and decreased color stability during retail display.

Key words: beef, distillers grains, fatty acids, sensory traits. 


\section{INTRODUCTION}

Wet distillers grains plus solubles (WDGS) have been used widely in beef cattle finishing diets. Distillers grains are obtained as ethanol co-products after screening and pressing or centrifugation (Larson et al., 1993). The advantages of feeding WDGS to cattle include reduced production costs and improved ADG, increased marbling score, and improved feed conversion when compared with other protein sources (Bremer et al., 2008). Vander Pol et al. (2005) reported that feeding up to 50\% of WDGS in finishing diets improved ADG and G:F when compared to feeding high moisture/dry rolled corn. Shand et al. (1998) reported that carcass traits, proximate composition and fatty acid composition were unaffected by wheat-based WDGS diets. This may be due to the lower fat concentration of wheat-based WDGS when compared to corn-based. However, diet formulation may affect beef quality, composition and ultimately shelf life due to increases in polyunsaturated fatty acids (PUFA) (Nelson et al., 2004).

Roeber et al. (2005) showed that inclusion of distillers grains in finishing diets at high rates (40 to 50\%, DM basis) had negative effects on beef color but levels up to $25 \%$ were not detrimental to color during retail display. Gill et al. (2008) reported lower L* values of beef (darker color) from animals fed 15\% corn-based distillers grains when compared to animals fed the same amount of sorghum-based wet distillers grains (WDG).

Alteration in fatty acid composition of beef has been shown to affect beef quality. High levels of PUFA are associated with higher values of oxidation and compromised beef color (Wood and Enser, 1997). Beef from animals fed dry distillers grains possessed higher concentrations of omega 6 fatty acids and omega 6:omega 3 ratios when compared to steam-flaked corn (Gill et al., 2008). In addition, oxidation of fatty acids results in 
products like ketones and aldehydes which negatively affect beef flavor and color shelflife (Liu et al., 1995; Jakobsen and Bertelsen, 2000).

In this study we hypothesized that feeding levels up to 30\% of WDGS would not alter marbling, lipid content, objective, and subjective tenderness. Additionally, we also hypothesized that feeding WDGS would increase proportions of PUFA, lipid oxidation, and cause detrimental effects on beef color. Therefore, the objectives of this study were to identify the effects of finishing diets containing WDGS on fatty acids and color.

\section{MATERIALS AND METHODS}

ANIMALS

Initially, ninety-six, calf-fed crossbred steers were blocked by BW and randomly distributed to pen (8 steers/pen). Dietary treatments consisted of three different inclusions of WDGS replacing corn $(0 \%, 15 \%$ or $30 \%$ wet distillers grains plus solubles - WDGS -

DM basis; Table 1). Steers were fed for $167 \mathrm{~d}$. The base diet consisted of dried rolled corn, high moisture corn and alfalfa hay. Steers were implanted on d 1 with Synovex Choice (14 mg E2, 100 mg TBA; Fort Dodge Animal Health, Overland Park, KS) followed by Revelor-S (24 mg E $2120 \mathrm{mg}$ TBA; Schering-Plough/Intervet Inc., Somerville, N.J.) on d 67. Details of feeding methods and cattle performance were reported by Luebbe (2009). For this experiment, 94 ribeye slices were collected for fatty acid analysis of the Longissimus muscle (31, 31, and 32 steers from 0, 15, and 30\% WDGS, respectively). For other analysis, 48 strip loins, top blades, and tenderloins were randomly sub sampled from the 94 steers (16 per treatment). In this experiment, the animal was considered the experimental unit due to sampling conditions at the commercial plant. 


\section{CARCASS AND FABRICATION}

Steers were harvested at a commercial plant (Greater Omaha Packing Co., Omaha, NE) and at $48 \mathrm{~h}$ postmortem, marbling score, marbling texture and marbling distribution were assessed by a USDA grading supervisor. Forty-eight carcasses, 16 from each treatment, were randomly selected from the 94 and their respective short loins (IMPS \#174, NAMP, 2007) and shoulder clods (IMPS \#114, NAMP, 2007) were removed, vacuum packaged, and shipped to the Loeffel Meat Laboratory at the University of Nebraska. After $7 \mathrm{~d}$ aging ( $7 \mathrm{~d}$ postmortem) at $5 \pm 2{ }^{\circ} \mathrm{C}$, the strip loins (Longissimus lumborum) and tenderloins (Poas major) were excised from the short loins and the top blades (Infraspinatus) from the shoulder clods.

\section{SAMPLE PREPARATION}

Forty-eight h postmortem, carcasses were graded and a $7 \mathrm{~mm}$ thick ribeye slice (Longissimus thoracis) was excised from each carcass $(n=94)$ at the $12^{\text {th }} / 13^{\text {th }}$ rib interface, placed in Whirl-Pac bags and transferred on ice in an insulated container to the Loeffel Meat Laboratory at the University of Nebraska within 1 h. Ribeye slices were trimmed of subcutaneous fat and epimysial connective tissue, submerged in liquid $\mathrm{N}$, pulverized and stored at $-80^{\circ} \mathrm{C}$. For ribeye slices, total lipid content, fatty acid profile and proximate composition were evaluated.

After fabrication, four $2.54 \mathrm{~cm}$ thick steaks were cut from each strip loin, tenderloin and top blade. The first and second steaks were vacuum packaged, frozen ($16^{\circ} \mathrm{C}$ ), and used for sensory, and objective tenderness analyses, respectively. The third steak was vacuum packaged and frozen immediately until the sample could be pulverized in liquid nitrogen with a blender (Waring Commercial, model 51BL32, Torring, CT). Lipid oxidation, fatty acid profile, and mineral composition were then evaluated. The 
fourth steak was divided in equally sized halves. The pieces were placed on Styrofoam trays and wrapped in oxygen-permeable film to be exposed to simulated retail display for 4 or $7 \mathrm{~d}$ prior to lipid oxidation analysis.

\section{LABORATORY ANALYSES}

Moisture and ash values were quantified using a LECO Thermogravimetric Analyzer (LECO Corporation, model 604-100-400, St. Joseph, MI). Total fat was determined by ether extraction using the Soxhlet procedure (AOAC, 1990).

For fatty acids, total lipid was extracted following the chloroform-methanol procedure of Folch et al. (1957). After extraction, the lipids were converted to fatty acid methyl esters according to Morrison and Smith (1964) and Metcalfe et al. (1966), and analyzed using gas chromatography (Hewlett-Packard Gas Chromatograph - Agilent Technologies, model 6890 series, Santa Clara, CA). Samples were analyzed using a capillary column (Chrompack CP-Sil 88 (0,25 mm x $100 \mathrm{~m})$. Oven temperature was programmed from 140 to $220^{\circ} \mathrm{C}$ at $2^{\circ} \mathrm{C} / \mathrm{min}$ and held at $220^{\circ} \mathrm{C}$ for $20 \mathrm{~min}$. Injector and detector temperature were maintained at 270 and $300^{\circ} \mathrm{C}$, respectively. The carrier gas was Helium at a flow rate of $30 \mathrm{~mL} / \mathrm{min}$. Fatty acids were identified by comparison of retention times with known standards. In this experiment, after analyzing the fatty acid profile of ribeyes, an upgrade of standards was realized allowing the identification of more fatty acids. Therefore, no estimation of total omega 6 and omega 6: omega 3 could be calculated on ribeye slices.

Mineral composition (mg/kg) was determined by atomic absorption spectroscopy following the methodology of Ward and Gray (1994). Minerals that were quantified included Ca, P, K, Mg, S, Na, Zn, Fe, Mn and Cu. 
Lipid oxidation was measured by the thiobarbituric acid assay (TBA) according to the protocol of Buege and Aust (1978), modified by Ahn et al. (1998), at 0, 3 and 7 days of display.

\section{SIMULATED RETAIL DISPLAY}

Two display retail cases (LNSC5 - Tyler Refrigeration Corporation, Niles, MI) maintained at $2 \pm 2^{\circ} \mathrm{C}$ were used for retail display. Samples were randomly placed in the cases and exposed to continuous fluorescent lightning $($ Lamp type $=$ F32T8/TL850 ALTO; Phillips, Inc., New Jersey, USA) with intensity of 1614 lx.

\section{OBJECTIVE COLOR}

Objective color measurement was obtained for L* (psychometric lightness; black $=0$, white $=100), a^{*}($ red $=$ positive values; green $=$ negative values $)$ and $\mathrm{b}^{*}($ yellow $=$ positive values; blue $=$ negative values $)$ using a HunterLab colorimeter (45/0-LAV Miniscan XE Plus, Hunter Associates Laboratory, Inc., Virginia, U.S.A.) with a 35 mm diameter measurement area, a D65 illuminant and $10^{\circ}$ standard observer. The colorimeter was calibrated daily using black and white ceramic titles provided by the manufacturer. Color measures were obtained at 1, 3, 4, 5, 6 and $7 \mathrm{~d}$ of display by averaging three readings from different areas of the steak surface.

\section{SENSORIAL ANALYSIS AND OBJECTIVE TENDERNESS (WARNER-BRATZLER SHEAR FORCE, WBSF)}

Seven-day aged steaks for trained taste panel and WBSF analysis were thawed for $24 \mathrm{~h}$ at $5^{\circ} \mathrm{C}$ and grilled to $70^{\circ} \mathrm{C}$. Steaks were flipped after reaching $35^{\circ} \mathrm{C}$ at the geometric center. Internal temperature was monitored by using a digital thermometer (model 450ATT, Omega Engineering, Stamford, CT) with a type $\mathrm{T}$ thermocouple (Omega Engineering). An experienced seven-member beef attributes panel was trained to evaluate 
all muscles. Panelists were trained according Meilgaard et al. (1991) to evaluate tenderness, connective tissue amount, juiciness, and off-flavor intensity on 8-point hedonic scales. Attributes were rated from $1=$ extremely tough to $8=$ extremely tender (tenderness); $1=$ abundant amount to $8=$ no connective tissue (connective tissue amount); 1 = extremely dry to $8=$ extremely juicy (juiciness); and $1=$ extremely offflavor to 8 = no off-flavor (off-flavor intensity). To avoid visual differences, samples were served under a red fluorescent light and unsalted crackers and double distilled, deionized water were available to the panelists to cleanse their palates between the samples. For WBSF, after cooking, steaks were cooled for $1 \mathrm{~h}$ at $4^{\circ} \mathrm{C}$ and cores were removed with a drill press parallel to muscle fiber orientation. At least 6 cores $(1.27 \mathrm{~cm}$ in diameter) from each steak were sheared on an Instron Universal Testing Machine (model 55R1123, Instron Corp., Canton, MA) with a Warner-Bratzler blade and the average of the cores represented the shear force for a given steak. The crosshead speed was $250 \mathrm{~mm} / \mathrm{min}$ with a $500 \mathrm{~kg}$ load cell.

\section{STATISTICAL ANALYSIS}

Oxidation data (TBA values) were analyzed as a split plot where diet was the whole plot and day the split plot. Effects of diet and day were considered main effects. Animal (whole muscle) within diet was considered the whole plot and day by diet the split plot error terms, respectively. Color data were analyzed as a split plot repeated measures design. The compound symmetry covariance matrix was used due to smaller AIC and BIC coefficients. Sensory data were analyzed as a completely randomized design and panelist was considered a random effect. Animal (whole muscle) within diet was considered the whole plot error term and panelist by diet the split plot error term. The Kenward-Rogers degrees of freedom approximation was used. Mineral, fatty acid profile 
and fat content data were arranged on a complete randomized design. For fatty acids and TBA values, response curves were also used to detect linear and quadratic relationships. The test for homogeneity of regression slopes was conducted for marbling score versus fat percentage using the GLM procedure of SAS (Version 9.1, Cary, N.C., 2002).

Data were analyzed using the GLIMMIX procedure of SAS (Version 9.1, Cary, N.C., 2002). When significance $(P \leq 0.05)$ was indicated by ANOVA, means separations were performed using the LSMEANS and DIFF functions of SAS.

\section{RESULTS AND DISCUSSION}

\section{MARBLING AND FAT}

There were linear relationships between marbling score and fat percentage in the ribeye (Figure 1), regardless of amount of WDGS in the diet. The coefficients of determination ranged from $21-40 \%$. Slopes were statistically similar at $P=0.72$ indicating an equal rate of change between fat content and marbling among the 3 diet treatments. This means feeding WDGS does not alter the ability of a federal grader to visualize intramuscular fat. Feeding WDGS did not affect fat $(P=0.49$ and $P=0.43)$, moisture ( $P=0.63$ and $P=0.17)$, or ash $(P=0.44$ and $P=0.67)$ contents in the top blade and tenderloins, respectively.

Feeding grains (starch) supports more propionate production in the rumen, which is responsible for $75 \%$ of marbling deposition whereas acetate, produced from digestion of grass (fiber), is responsible for $75 \%$ of subcutaneous fat deposition (Smith and Crouse, 1984). During the corn dry-milling process starch is removed from the grains, resulting in distillers grains with more fiber than ground corn. Conceivably, this feedstuff could move fat deposition away from marbling and toward subcutaneous fat. 
However, our study showed that feeding 15 or 30\% WDGS did not significantly influence marbling score, marbling texture, marbling distribution or fat content when compared to 0\% WDGS (Table 2). Even with starch removal, Vander Pol et al. (2009) showed that feeding distillers grains stimulated higher propionate production in the rumen, which could help to explain our results. In a meta analysis of multiple studies concerning inclusion of WDGS in cattle diets, Bremer et al. (2008) showed an increase in marbling up to $40 \%$ of dietary WDGS (DM basis).

\section{FATTY ACIDS}

Fatty acid values are shown in Tables 3, 4, and 5 for ribeye, tenderloin and top blade, respectively. For all muscles, values of PUFA, 18:2 (n-6), and omega 6 linearly increased as WDGS levels increased. Except for tenderloin steaks, total trans fatty acids also linearly increased in response to WDGS level. Major components of the saturated fatty acid group, 16:0 and 18:0, responded differently to feeding WDGS. For tenderloins and top blades, a linear decrease was observed in 16:0 as levels of WDGS increased in the diet. For ribeyes, although a linear decrease was not observed $(P=0.29)$, steaks from animals fed 30\% WDGS had lower 16:0 when compared to steaks from steers fed 0\% WDGS $(P<0.01)$. Values of 18:0 linearly increased $(P<0.01)$ in ribeyes and a similar trend $(P=0.07)$ was observed for top blades. Feeding WDGS did not alter values of 18:0 for tenderloin steaks.

For top blades and ribeyes, 18:1 trans fatty acids (18:1t) showed a linear increase as dietary levels of WDGS increased $(P<0.01)$. No differences in proportions of 18:1 trans fatty acids were observed for tenderloins $(P=0.56)$. 
In our study, feeding WDGS created higher values of omega 6:omega 3 for tenderloins and top blades. Similar results regarding omega 6 and omega 6:omega 3 were found by Gill et al. (2008) when comparing distillers grains to steam flake corn.

Modification of beef fatty acid profiles by feeding WDGS likely occurs because this feedstuff has a higher level of lipid and greater fat digestibility when compared to corn (Lodge et al., 2007; Vander Pol et al., 2009). In addition, Vander Pol et al. (2009), analyzed fatty acids passing through the rumen and observed that feeding WDGS led to higher levels of 18:2 and 18:1t in the duodenum when compared to corn, which may result in higher deposition of those fatty acids in the muscle. This explains higher levels of 18:2(n-6) and PUFA in all muscles, as well as higher levels of 18:1t and total trans fatty acids in Longissimus and Infraspinatus from our study.

These results contradict Shand et al. (1998), who found no impacts on fatty acid composition in beef from animals fed wheat-based wet distillers grains (WDG) and wet brewers grains (WBG). Considering that corn-based WDGS have higher fat concentration when compared to wheat-based, our study demonstrated that corn-based wet distillers grains modify the fatty acid profile of beef.

\section{SENSORY ANALYSIS AND OBJECTIVE TENDERNESS.}

Results of sensory analysis and WBSF are presented in Table 6. Feeding WDGS did not affect WBSF and sensory attributes of top blade and tenderloin steaks. Despite a significant but slight decline in strip steak juiciness at 15\% WDGS, no patterns on other sensory traits were observed for any muscle regarding levels of WDGS. 
In the present study, feeding WDGS led to a linear decrease of 18:1(n-7) in all muscles $(P<0.01)$. Camfield et al. (1997) showed that lower values of 18:1(n-7) may lead beef to liver, sour and metallic off-flavor. A similar trend was observed by Jenschke et al. (2007), reaffirming that there is an inverse relationship between liver off-flavor and levels of 18:1(n-7). In our study, although we detected lower values of 18:1(n-7), panelists did not detect a significant presence of off-flavors in beef from animals fed any dietary treatment. However, steaks for sensory analysis were not subject to retail display, when oxidation could contribute to development of off flavors.

\section{MiNERAL COMPOSITION}

Feeding WDGS did not alter mineral composition of top blades and strip loins (Table 7). Sulfur-based compounds are sometimes associated with off-flavor of beef (Brewer, 2006). In this study, tenderloins from steers finished with 30\% WDGS had significantly lower levels of S $(P=0.05)$ than 0 and 15\% WDGS. Other minerals such as Na are correlated to off-flavor development of beef (Jenschke et al., 2007). In our study no effects on sodium were observed as WDGS levels were increased.

\section{LIPID OXIDATION}

A significant interaction between retail display day and WDGS treatments was observed for top blade and strip loin. Top blade steaks from cattle fed 30\% WDGS had higher oxidation (higher TBA values) $(P<0.01)$ after $7 \mathrm{~d}$ of display when compared to 0 and 15\% WDGS (Table 8); similar results were observed for strip loins $(P<0.01)$ and a linear increase was identified for both muscles $(P=0.02)$ at day 7 (Table 8). No WDGS effects were identified on TBA values of tenderloin steaks ( $P=0.19$; data not shown). 
Zhang et al. (2007) showed that PUFA are more easily oxidized when compared to saturated fatty acids. This research clearly demonstrated a linear increase of PUFA in all analyzed muscles as WDGS levels increase in diets. Consequently, high oxidation values observed after $7 \mathrm{~d}$ of retail display for top blade and strip loin steaks are likely associated with the increase in PUFA. In this study, high levels of corn-based WDGS in finishing diets supported higher oxidation of strip loin and top blade steaks.

\section{OBJECTIVE COLOR}

Meat redness values $\left(a^{*}\right)$ are presented in figures 2a, 2b, and 2c for strip loin, tenderloin, and top blade steaks, respectively. Strip loin steaks from steers fed 15 and $30 \%$ WDGS were less red (lower $\mathrm{a}^{*}$ values) when compared to $0 \%(P<0.05)$ after $7 \mathrm{~d}$ of display. For tenderloin steaks, lower $\mathrm{a}^{*}$ values were observed on day 3 and 5 of retail display for beef from cattle fed 15 and 30\% WDGS. For top blades, steaks from animals fed $30 \%$ were less red throughout the display time than steaks from cattle fed 0\%WDGS.

Roeber et al. (2005) reported that finishing diets including distillers grains at high rates (40 to 50\% - DM basis) may negatively affect color stability of strip loin steaks, although low to moderate levels (10 to 25\%) could be included in the diet with no detrimental effects. Data from the present study showed that levels up to $15 \%$ may influence color desirability after $7 \mathrm{~d}$ of retail display for strip loin steaks (Figure 2a). Top blade color was compromised when steers were fed 30\% WDGS. In the muscle, myoglobin is responsible for red color. When myoglobin is oxidized to metmyoglobin, detrimental effects on color can be observed (Liu et al., 1996). In addition, myoglobin and lipid oxidation are closely correlated (Arnold et al., 1993). Thus, propagation of 
oxidation by PUFA from WDGS appears to reduce color desirability during retail display.

Higher values of a* are associated with desirable visual appearance (Zerby et al., 1999). According to Steiner et al. (2001), consumers consider color and discoloration when selecting beef products in the display case. Normally, from 2 to $20 \%$ of fresh beef in U.S. retail stores is discounted or discarded due to loss of desirable color (Sherbeck et al., 1995). Compromising color by feeding WDG may increase this percentage.

\section{CONCLUSION}

Distillers grains are widely-used as a way of decreasing the cost of beef production. However, the inclusion of 30\% of WDGS in finishing diets increased PUFA and oxidation of beef, resulting in shorter shelf life. 


\section{LITERATURE CITED}

Ahn, D. U., D.G. Olsen, C. Jo, X. Chen, C. Wu, and J. I. Lee. 1998. Effect of muscle type, packaging and irradiation on lipid oxidation, volatile production and color in raw pork patties. Meat Sci. 49:27-39.

AOAC. 1990. Official Methods of Analysis. $15^{\text {th }}$ ed. Assoc. Off. Anal. Chem., Arlington, VA.

Arnold, R. N., S. C. Arp, K. K. Scheller, S. N. Williams, and D. M. Schaefer. 1993. Tissue equilibration and subcellular distribution of vitamin $\mathrm{E}$ relative to myoglobin and lipid oxidation in displayed beef. J. Anim. Sci. 71:105-118.

Bremer,V.B., G.E. Erickson, and T.J. Klopfenstein. 2008. Meta-Analysis of UNL Feedlot Trials Replacing Corn with WDGS. Nebraska Beef Cattle Report. MP91:35-36.

Brewer, M.S. 2006. The Chemistry of Beef Flavor - Executive Summary. Prepared for the National Cattlemen's Beef Association, Centennial, CO.

Buege, J. A., and S.D. Aust. 1978. Microsomal lipid peroxidation. Methods Enzymol. 52: 302-310.

Camfield, P. K., A. H. Brown, Jr., P. K. Lewis, L. Y. Rakes, and Z. B. Johnson. 1997. Effects of frame size, and time-on-feed on carcass characteristics, sensory attributes, and fatty acid profiles of steers. J. Anim. Sci. 75:1837-1844.

Carrete, J. and N.A. Pensel. 2007 Antioxidant status and odour profile in fresh beef from pasture or grain-fed cattle. Meat Sci. 75: 299-307. 
Crouse, J. D., H. R. Cross, and S. C. Seidman. 1984. Effects of a grass or grain diet on the quality of three beef muscles. J. Anim. Sci. 58: 619-625.

Descalzo, A. M., L. Rossetti, G. Grigioni, M. Irurueta and A.M. Sancho. 2007. Antioxidant status and odour profile in fresh beef from pasture or grain-fed cattle. Meat Sci. 75:299-307.

Folch, J., M. Lees, and G.H.S. Stanley. 1957. A simple method for the isolation and purification of total lipids from animal tissues. J. Biol. Chem. 226:497-509.

Gill, R. K., D. L. VanOverbeke, B. Depenbusch, J. S. Drouillard, and A. DiCostanzo. 2008. Impact of beef cattle diets containing corn or sorghum distillers grains on beef color, fatty acid profiles, and sensory attributes. J Anim. Sci. 86:923-935.

Jakobsen, M., G. Bertelsen. 2000. Colour stability and lipid oxidation of fresh beef. Development of a response surface model for predicting the e€ects of temperature, storage time, and modified atmosphere composition. Meat Sci. 54:49-57.

Jenschke, B. J., J.M. Hodgen, J.L. Meisinger, A.E. Hamling, D.A. Moss, M. Lundesjö Ahnström, K.M. Eskridge, and C.R. Calkins. 2007. Unsaturated fatty acids and sodium affect the liver-like off flavor in cooked beef J. Anim. Sci. 85:3072-3078.

Larson, E.M., R. A. Stock, T. J. Klopfenstein, M. H. Sindt, and R. P. Huffman. 1993. Feeding value of wet distillers byproducts. J. Anim. Sci. 71:2228-2236

Liu, M., C. Lanari, and D. M. Schaefer. 1995. A review of dietary vitamin E supplementation for improvement of beef quality. J. Anim. Sci. 73:3131-3140. 
Luebbe, M. K. 2009. Nutrient Management in Beef Feedlots. PhD Diss. University of Nebraska, Lincoln.

Meilgaard, M., G. V. Civille, and B. T. Carr. 1991. Sensory Evaluation Techniques, 2nd ed. CRC Press Inc., Boca Raton, FL.

Metcalfe, L.D., A.A. Schmitz, and J.R. Pelka. 1966. Rapid preparation of fatty acid esters from lipids for gas chromatographic analysis. Anal. Chem. 38:514-515.

Metton S.L., M. Amiri, G. W. Davis, and W. R. Backus. 1982. Flavor and chemical characteristics of ground beef from grass, forage-grain and grain finished steers. J. Anim. Sci. 55:77-87.

Morrison, W.R. and L.M. Smith. 1964. Preparation of fatty acid methyl esters and dimethylacetals from lipids with boron fluoride-methanol. J. Lipid Res. 5:600-608.

NAMP. 2007. The Meat Buyers Guide. North Am. Meat Processors Assoc., Reston, VA.

Nelson, M. L., D. J. Marks, J. R. Busboom, J. D. Cronrath and L. Falen. 2004. Effects of supplemental fat on growth performance and quality of beef from steers fed barleypotato product finishing diets: I. Feedlot performance, carcass traits, appearance, water binding, retail storage, and palatability attributes. J. Anim. Sci. 82:3600-3610.

Noci, F., F. J. Monahan, P. French, and A. P. Moloney. 2005. The fatty acid composition of muscle fat and subcutaneous adipose tissue of pasture-fed beef heifers: Influence of the duration of grazing. J. Anim. Sci. 83:1167-1178. 
O’Sullivan, A., K. O’Sullivan, K. Galvin, A. P. Moloney, D. J. Troy, and J. P. Kerry. 2002. Grass silage versus maize silage effects on retail packaged beef quality. J. Anim. Sci. 80:1556-1563.

Roeber, D. L., R. K. Gill, and A. DiConstanzo. 2005. Meat quality responses to feeding distillers grains to finishing Holstein steers. J. Anim. Sci. 83:2455-2460.

Shand, P. J., J. J. McKinnon, and D.A. Christensen. 1998. Eating quality of beef from animals fed wet brewers' grains and wheat-based wet distillers' grains. Can. J. Anim. Sci. 78:143-146.

Sherbeck, J.A., D.M. Wulf, J. B. Morgan, J. D. Tatum, and G. C. Smith. 1995. Dietary supplementation of vitamin E to feedlot cattle affects beef retail display properties. J. Food Sci. 60: 250-252.

Smith, S. B., and J. D. Crouse. 1984. Relative contributions of acetate, lactate and glucose to lipogenesis in bovine intramuscular and subcutaneous adipose tissue. J. Nutr. 114:792-800.

Spiehs, M.J., M. H. Whitney and G. C. Shurson. 2002. Nutrient database for distillers dried grains with solubles produced from new ethanol plants in Minnesota and South Dakota. J. Anim. Sci. 80:2639-2645.

Steiner R., K. E. Belk, and G. C. Smith. 2001. Determination of bloom time and caselife of Nolan Ryan ground beef. http://ansci.colostate.edu/files/meat_science/rs013.pdf. Acessed April 04, 2008. 
Vander Pol, K., G. Erickson, T. Klopfenstein and M. Greenquist. 2005. Effect of level of wet distillers grains on feedlot performance of finishing cattle and energy value relative to corn. J. Anim. Sci. 83 (Suppl. 2):55. (Abstr.)

Vander Pol, K., M. Luebbe, G. I. Crawford, G. Erickson and T. Klopfenstein. 2009. Performance and digestibility characteristics of finishing diets containing distillers grains, composites of corn processing coproducts, or supplemental corn oil. J. Anim. Sci. 87:639-652.

Ward, M., and Gray, M., 1994. Vapour Generation Assembly VGA-77 Operational Manual Safety class 1 (1 EC 1010-1) Varian Publication No. 8510104700.

Wood, J. D., and M. Enser. 1997. Factors influencing fatty acids in meat and the role of antioxidants in improving meat quality. Brit. J. Nutr. 78 (Suppl. 1): 49-60.

Zerby, H. N., K. E. Belk, J. N. Sofos, L. R. McDowell, and G. C. Smith. 1999. Case life of seven retail products from beef cattle supplemented with $\alpha$-tocopheryl acetate. J. Anim. Sci. 77:2458-2463.

Zhang, W., B. Shi, J. Shi. 2007. A theoretical study on autoxidation of unsaturated fatty acids and antioxidant activity of phenolic compounds. J. Am. Leath. Chem. Ass. 102:99-105. 
Table 1. Composition of treatment diets on a dry matter basis.

\begin{tabular}{lccc}
\hline & \multicolumn{3}{c}{ Dietary treatments (\%, WDGS) } \\
\cline { 2 - 4 } Ingredients & 0 & 15 & 30 \\
\hline Dry rolled corn & 41.25 & 33.75 & 26.25 \\
High moisture corn & 41.25 & 33.75 & 26.25 \\
Alfalfa hay & 7.5 & 7.5 & 7.5 \\
WDGS & - & 15 & 30 \\
Molasses & 5 & 5 & 5 \\
Fine ground corn & 1.74 & 2.97 & 2.97 \\
Tallow & 0.13 & 0.13 & 0.13 \\
Limestone & 1.44 & 1.5 & 1.5 \\
Salt & 0.3 & 0.3 & 0.3 \\
Calcium sulfate & 0.13 & - & - \\
Beef trace mineral & 0.05 & 0.05 & 0.05 \\
Vitamin A, D, E & 0.015 & 0.015 & 0.015 \\
Urea & 1.15 & - & - \\
Rumensin-80 & 0.014 & 0.014 & 0.014 \\
Tylan-40 & 0.008 & 0.008 & 0.008 \\
Thiamine & 0.011 & 0.011 & 0.011 \\
\hline
\end{tabular}


Table 2. WDGS finishing diets effects on marbling and fat content of the ribeye (Longissimus thoracis).

\begin{tabular}{lcccc}
\hline & \multicolumn{3}{c}{ Dietary treatments $^{\mathrm{a}}$} & \\
\cline { 2 - 4 } Attributes & 0 & 15 & 30 & $P$-value \\
\hline Marbling score $^{\mathrm{b}}$ & Slight $^{93}$ & Small $^{03}$ & Small $^{04}$ & 0.46 \\
Marbling texture $^{\mathrm{c}}$ & 1.60 & 1.58 & 1.52 & 0.84 \\
Marbling distribution $^{\mathrm{d}}$ & 1.29 & 1.15 & 1.22 & 0.40 \\
Fat, \% & 5.44 & 5.91 & 5.94 & 0.19 \\
\hline
\end{tabular}

${ }^{\mathrm{a}}$ Wet distillers grains plus solubles (\%, DM basis).

${ }^{\mathrm{b}}$ Slight $=300-399$, Small $=400-499$.

${ }^{\mathrm{c}}$ Fine $=1$, Medium $=2$, Coarse $=3$.

${ }^{\mathrm{d}}$ Even $=1$, Uneven $=2$. 
Table 3. Weight percentage of fatty acids ${ }^{1}$ and fat content of ribeye slices (Longissimus thoracis) from steers fed wet distillers grains plus solubles (WDGS) finishing diets.

\begin{tabular}{|c|c|c|c|c|c|c|}
\hline \multirow[b]{2}{*}{ Fatty acid } & \multicolumn{3}{|c|}{ Dietary treatments $^{2}$} & \multirow[b]{2}{*}{$P$-value } & \multicolumn{2}{|c|}{ Effects $^{3}$} \\
\hline & 0 & 15 & 30 & & Linear & Quadratic \\
\hline $14: 0$ & 2.94 & 2.96 & 2.84 & 0.50 & 0.25 & 0.09 \\
\hline $14: 1(n-5)$ & $0.64^{\mathrm{a}}$ & $0.63^{\mathrm{a}}$ & $0.54^{\mathrm{b}}$ & 0.04 & 0.25 & 0.09 \\
\hline $15: 0$ & $0.51^{\mathrm{b}}$ & $0.57^{\mathrm{a}}$ & $0.49^{\mathrm{b}}$ & 0.02 & 0.25 & $<0.01$ \\
\hline iso16:0 & 0.93 & 0.90 & 0.81 & 0.22 & 0.43 & 0.27 \\
\hline $16: 0$ & $26.35^{\mathrm{a}}$ & $25.83^{\mathrm{ab}}$ & $25.12^{\mathrm{b}}$ & $<0.01$ & 0.29 & 0.13 \\
\hline $16: 1(n-7)$ & $3.50^{\mathrm{a}}$ & $3.23^{\mathrm{b}}$ & $2.90^{\mathrm{C}}$ & $<0.01$ & 0.29 & 0.11 \\
\hline $17: 0$ & $1.43^{\mathrm{b}}$ & $1.66^{\mathrm{a}}$ & $1.43^{\mathrm{b}}$ & 0.01 & 0.15 & $<0.01$ \\
\hline iso18:0 & 0.66 & 0.73 & 0.64 & 0.24 & 0.54 & 0.01 \\
\hline $17: 1(n-7)$ & $1.08^{\mathrm{ab}}$ & $1.17^{\mathrm{a}}$ & $0.98^{\mathrm{b}}$ & 0.03 & 0.79 & $<0.01$ \\
\hline $18: 0$ & $13.76^{\mathrm{b}}$ & $14.13^{b}$ & $15.03^{\mathrm{a}}$ & 0.02 & $<0.01$ & 0.33 \\
\hline $18: 1 t$ & $2.28^{\mathrm{b}}$ & $2.61^{\mathrm{b}}$ & $3.76^{\mathrm{a}}$ & $<0.01$ & $<0.01$ & 0.35 \\
\hline 18:1(n-9) & $36.14^{\mathrm{a}}$ & $34.66^{\mathrm{b}}$ & $34.02^{b}$ & $<0.01$ & 0.46 & 0.20 \\
\hline $18: 1(n-7)$ & $3.20^{\mathrm{a}}$ & $2.77^{\mathrm{b}}$ & $2.41^{\mathrm{c}}$ & $<0.01$ & 0.02 & 0.13 \\
\hline 19:0 & 0.02 & 0.01 & 0.04 & 0.29 & 0.21 & 0.68 \\
\hline $18: 2(n-6)$ & $3.27^{\mathrm{b}}$ & $4.22^{\mathrm{a}}$ & $4.50^{\mathrm{a}}$ & $<0.01$ & $<0.01$ & 0.04 \\
\hline $20: 0$ & $0.005^{\mathrm{b}}$ & $0.007^{\mathrm{b}}$ & $0.03^{\mathrm{a}}$ & 0.02 & 0.03 & 0.75 \\
\hline 18:3(n-3) & 0.07 & 0.09 & 0.06 & 0.51 & 0.89 & 0.09 \\
\hline 20:1(n-9) & 0.15 & 0.16 & 0.20 & 0.06 & $<0.01$ & 0.73 \\
\hline $20: 3(n-6)$ & $0.29^{\mathrm{b}}$ & $0.33^{\mathrm{ab}}$ & $0.35^{\mathrm{a}}$ & 0.05 & $<0.01$ & $<0.01$ \\
\hline $20: 4(n-6)$ & 1.06 & 1.02 & 1.03 & 0.92 & 0.25 & 0.93 \\
\hline Others & 1.52 & 2.06 & 2.56 & $<0.01$ & $<0.01$ & 0.37 \\
\hline Total Trans & $2.87^{\mathrm{c}}$ & $3.61^{\mathrm{b}}$ & $4.86^{\mathrm{a}}$ & $<0.01$ & $<0.01$ & 0.33 \\
\hline PUFA & $4.90^{\mathrm{b}}$ & $5.91^{\mathrm{a}}$ & $6.23^{\mathrm{a}}$ & $<0.01$ & $<0.01$ & 0.29 \\
\hline SFA & 46.60 & 46.79 & 46.42 & 0.79 & 0.72 & 0.65 \\
\hline Omega 3 & $*$ & $*$ & $*$ & $*$ & $*$ & $*$ \\
\hline Omega 6 & $4.62^{\mathrm{b}}$ & $5.60^{\mathrm{a}}$ & $5.86^{\mathrm{a}}$ & $<0.01$ & $<0.01$ & 0.47 \\
\hline Omega 6:Omega 3 & $*$ & $*$ & $*$ & * & $*$ & * \\
\hline
\end{tabular}

${ }^{1}$ Weight percentage values are relative proportions of all peaks observed by Gas Chromatography.

${ }^{2}$ Wet distillers grains plus solubles (\%, DM basis).

${ }^{3}$ Linear and quadratic response to WDGS level.

a,b,c Means in the same row having different superscripts are significant at $P \leq 0.05$ level.

*not estimated. 
Table 4. Weight percentage of fatty acids ${ }^{1}$ and fat content of tenderloin steaks (M. Psoas major) from steers fed wet distillers grains plus solubles (WDGS) finishing diets.

\begin{tabular}{|c|c|c|c|c|c|c|}
\hline \multirow[b]{2}{*}{ Fatty acid } & \multicolumn{3}{|c|}{ Dietary treatments $^{2}$} & \multirow[b]{2}{*}{$P$-value } & \multicolumn{2}{|c|}{ Effects $^{3}$} \\
\hline & 0 & 15 & 30 & & Linear & Quadratic \\
\hline $6: 0$ & 0.15 & 0.14 & 0.15 & 0.79 & 0.76 & 0.40 \\
\hline 10:0 & 0.03 & 0.03 & 0.02 & 0.90 & 0.93 & 0.94 \\
\hline 12:0 & 0.06 & 0.04 & 0.03 & 0.53 & 0.27 & 0.86 \\
\hline 14:0 & 2.92 & 2.93 & 2.69 & 0.18 & 0.20 & 0.27 \\
\hline $14: 1(n-5)$ & $0.63^{\mathrm{ab}}$ & $0.69^{\mathrm{a}}$ & $0.57^{\mathrm{b}}$ & 0.05 & 0.21 & 0.03 \\
\hline $15: 0$ & 0.57 & 0.61 & 0.54 & 0.09 & 0.38 & 0.04 \\
\hline iso16:0 & 0.66 & 0.64 & 0.61 & 0.79 & 0.47 & 0.80 \\
\hline $16: 0$ & $26.36^{\mathrm{a}}$ & $25.45^{\mathrm{b}}$ & $24.62^{\mathrm{b}}$ & $<0.01$ & $<0.01$ & 0.09 \\
\hline 16:1(n-7) & $2.59^{\mathrm{a}}$ & $2.53^{\mathrm{a}}$ & $2.06^{\mathrm{b}}$ & $<0.01$ & $<0.01$ & 0.09 \\
\hline $17: 0$ & 1.53 & 1.58 & 1.45 & 0.16 & 0.21 & 0.15 \\
\hline iso18:0 & 0.46 & 0.51 & 0.53 & 0.57 & 0.41 & 0.99 \\
\hline $17: 1(n-7)$ & 0.98 & 0.90 & 0.78 & 0.10 & 0.03 & 0.83 \\
\hline $18: 0$ & 15.64 & 15.46 & 16.58 & 0.15 & 0.12 & 0.22 \\
\hline $18: 1 t$ & 1.30 & 2.09 & 1.72 & 0.56 & 0.57 & 0.37 \\
\hline 18:1(n-9) & $35.31^{\mathrm{a}}$ & $34.55^{\mathrm{a}}$ & $33.12^{\mathrm{b}}$ & $<0.01$ & $<0.01$ & 0.56 \\
\hline 18:1(n-7) & $1.43^{\mathrm{a}}$ & $1.37^{\mathrm{a}}$ & $1.26^{\mathrm{b}}$ & 0.01 & $<0.01$ & 0.62 \\
\hline 19:0 & 0.10 & 0.10 & 0.12 & 0.15 & 0.05 & 0.58 \\
\hline $18: 2(n-6)$ & $3.08^{\mathrm{c}}$ & $4.07^{\mathrm{b}}$ & $4.80^{\mathrm{a}}$ & $<0.01$ & $<0.01$ & 0.66 \\
\hline $18: 2 t$ & 0.03 & 0.04 & 0.05 & 0.44 & 0.20 & 0.85 \\
\hline $20: 0$ & 0.10 & 0.10 & 0.12 & 0.44 & 0.24 & 0.96 \\
\hline 18:3(n-3) & 0.22 & 0.23 & 0.23 & 0.72 & 0.54 & 0.60 \\
\hline $20: 1(n-9)$ & 0.51 & 0.52 & 0.56 & 0.06 & 0.02 & 0.59 \\
\hline $20: 3(n-6)$ & 0.24 & 0.27 & 0.27 & 0.56 & 0.37 & 0.80 \\
\hline $20: 4(n-6)$ & 0.85 & 0.80 & 0.85 & 0.88 & 0.94 & 0.46 \\
\hline $22: 4(n-6)$ & 0.15 & 0.13 & 0.13 & 0.41 & 0.25 & 0.34 \\
\hline $22: 5(n-3)$ & $0.20^{\mathrm{a}}$ & $0.17^{\mathrm{ab}}$ & $0.15^{\mathrm{b}}$ & 0.04 & 0.01 & 0.78 \\
\hline Others & $3.83^{\mathrm{b}}$ & $3.97^{\mathrm{b}}$ & $5.90^{\mathrm{a}}$ & 0.03 & 0.01 & 0.23 \\
\hline Total Trans & 3.22 & 4.05 & 3.66 & 0.59 & 0.59 & 0.52 \\
\hline PUFA & $4.76^{\mathrm{b}}$ & $5.80^{\mathrm{a}}$ & $6.50^{\mathrm{a}}$ & $<0.01$ & $<0.01$ & 0.91 \\
\hline SFA & 48.60 & 47.52 & 47.44 & 0.21 & 0.14 & 0.51 \\
\hline Omega 3 & 0.42 & 0.41 & 0.38 & 0.19 & 0.07 & 0.90 \\
\hline Omega 6 & $4.34^{\mathrm{b}}$ & $5.23^{\mathrm{a}}$ & $6.05^{\mathrm{a}}$ & $<0.01$ & $<0.01$ & 0.92 \\
\hline Omega6:Omega3 & $10.09^{c}$ & $12.95^{\mathrm{b}}$ & $16.25^{\mathrm{a}}$ & $<0.01$ & $<0.01$ & 0.71 \\
\hline
\end{tabular}

${ }^{1}$ Weight percentage values are relative proportions of all peaks observed by Gas Chromatography.

${ }^{2}$ Wet distillers grains plus solubles (\%, DM basis).

${ }^{3}$ Linear and quadratic response to WDGS level.

${ }_{\mathrm{a}, \mathrm{b}, \mathrm{c}}$ Means in the same row having different superscripts are significant at $P \leq 0.05$ level. 
Table 5. Weight percentage of fatty acids ${ }^{1}$ and fat content of top blade steaks (Infraspinatus) from steers fed wet distillers grains plus solubles (WDGS) finishing diets.

\begin{tabular}{|c|c|c|c|c|c|c|}
\hline \multirow[b]{2}{*}{ Fatty acid } & \multicolumn{3}{|c|}{ Dietary treatments $^{2}$} & \multirow[b]{2}{*}{$P$-value } & \multicolumn{2}{|c|}{ Effects $^{3}$} \\
\hline & 0 & 15 & 30 & & linear & quadratic \\
\hline $6: 0$ & 0.17 & 0.18 & 0.18 & 0.79 & 0.87 & 0.78 \\
\hline 10:0 & 0.02 & 0.02 & 0.03 & 0.78 & 0.61 & 0.34 \\
\hline $12: 0$ & 0.02 & 0.03 & 0.02 & 0.37 & 0.86 & 0.10 \\
\hline 14:0 & 2.87 & 2.88 & 2.70 & 0.42 & 0.29 & 0.30 \\
\hline $14: 1(n-5)$ & $0.63^{\mathrm{ab}}$ & $0.70^{\mathrm{a}}$ & $0.52^{\mathrm{b}}$ & 0.01 & 0.06 & 0.02 \\
\hline $15: 0$ & $0.50^{\mathrm{ab}}$ & $0.56^{\mathrm{a}}$ & $0.47^{\mathrm{b}}$ & 0.03 & 0.45 & 0.01 \\
\hline iso16:0 & 0.66 & 0.66 & 0.68 & 0.93 & 0.84 & 0.76 \\
\hline $16: 0$ & $25.06^{\mathrm{a}}$ & $24.26^{\mathrm{b}}$ & $23.48^{\mathrm{b}}$ & $<0.01$ & 0.01 & 0.97 \\
\hline $16: 1(n-7)$ & $3.12^{\mathrm{a}}$ & $2.93^{\mathrm{a}}$ & $2.46^{\mathrm{b}}$ & $<0.01$ & $<0.01$ & 0.27 \\
\hline $17: 0$ & $1.54^{\mathrm{ab}}$ & $1.68^{\mathrm{a}}$ & $1.39^{\mathrm{b}}$ & 0.05 & 0.19 & 0.03 \\
\hline iso18:0 & 0.46 & 0.50 & 0.57 & 0.21 & 0.27 & 0.70 \\
\hline $17: 1(n-7)$ & $1.21^{\mathrm{a}}$ & $1.24^{\mathrm{a}}$ & $1.00^{\mathrm{b}}$ & $<0.01$ & 0.01 & 0.06 \\
\hline $18: 0$ & 14.52 & 14.51 & 15.37 & 0.19 & 0.07 & 0.35 \\
\hline $18: 1 t$ & $2.17^{c}$ & $2.79^{\mathrm{b}}$ & $4.03^{\mathrm{a}}$ & $<0.01$ & $<0.01$ & 0.29 \\
\hline $18: 1(n-9)$ & 38.46 & 37.37 & 36.52 & 0.06 & 0.02 & 0.86 \\
\hline $18: 1(n-7)$ & $1.73^{\mathrm{a}}$ & $1.58^{\mathrm{b}}$ & $1.47^{\mathrm{b}}$ & $<0.01$ & $<0.01$ & 0.80 \\
\hline 19:0 & 0.05 & 0.06 & 0.07 & 0.41 & 0.12 & 0.93 \\
\hline $18: 2(n-6)$ & $3.00^{\mathrm{c}}$ & $3.96^{\mathrm{b}}$ & $4.78^{\mathrm{a}}$ & $<0.01$ & $<0.01$ & 0.82 \\
\hline $18: 2 t$ & 0.01 & 0.00 & 0.00 & 0.25 & 0.52 & 0.22 \\
\hline $20: 0$ & 0.04 & 0.04 & 0.07 & 0.22 & 0.07 & 0.60 \\
\hline 18:3(n-3) & 0.16 & 0.16 & 0.18 & 0.43 & 0.98 & 0.18 \\
\hline 20:1(n-9) & 0.45 & 0.48 & 0.48 & 0.32 & 0.22 & 0.37 \\
\hline $20: 3(n-6)$ & 0.24 & 0.26 & 0.29 & 0.17 & 0.20 & 0.88 \\
\hline $20: 4(n-6)$ & 0.78 & 0.73 & 0.85 & 0.37 & 0.83 & 0.26 \\
\hline $22: 4(n-6)$ & 0.18 & 0.14 & 0.19 & 0.33 & 0.74 & 0.13 \\
\hline $22: 5(n-3)$ & $0.18^{\mathrm{a}}$ & $0.12^{\mathrm{ab}}$ & $0.10^{\mathrm{b}}$ & 0.04 & 0.01 & 0.67 \\
\hline Others & 1.89 & 2.13 & 2.08 & 0.58 & 0.33 & 0.34 \\
\hline Total Trans & $4.36^{\mathrm{b}}$ & $4.98^{\mathrm{b}}$ & $6.15^{\mathrm{a}}$ & $<0.01$ & $<0.01$ & 0.37 \\
\hline PUFA & $4.60^{\mathrm{b}}$ & $5.38^{\mathrm{ab}}$ & $6.40^{\mathrm{a}}$ & $<0.01$ & $<0.01$ & 0.81 \\
\hline SFA & 45.98 & 45.26 & 45.02 & 0.44 & 0.37 & 0.91 \\
\hline Omega 3 & 0.35 & 0.31 & 0.28 & 0.19 & 0.06 & 0.97 \\
\hline Omega 6 & $4.24^{\mathrm{c}}$ & $5.07^{\mathrm{b}}$ & $6.10^{\mathrm{a}}$ & $<0.01$ & $<0.01$ & 0.80 \\
\hline Omega6:Omega3 & $12.50^{\mathrm{b}}$ & $18.15^{\mathrm{b}}$ & $24.65^{\mathrm{a}}$ & $<0.01$ & $<0.01$ & 0.65 \\
\hline
\end{tabular}

${ }_{1}^{1}$ Weight percentage values are relative proportions of all peaks observed by Gas Chromatography.

${ }^{2}$ Wet distillers grains plus solubles (\%, DM basis).

${ }^{3}$ Linear and quadratic response to WDGS level.

${ }_{\mathrm{a}, \mathrm{b}, \mathrm{c}}$ Means in the same row having different superscripts are significant at $P \leq 0.05$ level. 
Table 6. Sensorial attributes ${ }^{1}$ and Warner-Bratzler shear force (WBSF) of ribeye, tenderloin, and top blade from steers fed wet distillers grains plus solubles (WDGS).

\begin{tabular}{llllll}
\hline Muscle & Attributes & \multicolumn{3}{c}{ Dietary treatments } & \\
\cline { 3 - 4 } & & 0 & 15 & 30 & $P$-value \\
\hline Ribeye (Longissimus lumborum) & & & & & \\
& Tenderness & 5.11 & 5.28 & 5.42 & 0.64 \\
& Connective tissue & 4.67 & 5.05 & 4.87 & 0.54 \\
& Juiciness & $5.32^{\mathrm{a}}$ & $4.86^{\mathrm{b}}$ & $5.52^{\mathrm{a}}$ & 0.02 \\
& Off-flavor & 2.62 & 2.57 & 2.56 & 0.84 \\
& WBSF, kg & 3.42 & 3.45 & 3.65 & 0.57 \\
& & & & & \\
Tenderloin (Poas major) & Tenderness & 6.73 & 6.76 & 6.55 & 0.48 \\
& Connective tissue & 6.40 & 6.54 & 6.24 & 0.20 \\
& Juiciness & 5.29 & 5.26 & 5.03 & 0.60 \\
& Off-flavor & 2.56 & 2.57 & 2.57 & 0.98 \\
& WBSF, kg & 2.62 & 2.77 & 2.71 & 0.52 \\
& & & & & \\
& Tenderness & 6.19 & 6.45 & 6.17 & 0.51 \\
& Connective tissue & 5.20 & 5.70 & 5.18 & 0.12 \\
& Juiciness & 6.05 & 6.11 & 6.12 & 0.97 \\
& Off-flavor & 2.93 & 3.06 & 2.84 & 0.56 \\
& WBSF, kg & 2.95 & 2.57 & 2.91 & 0.06 \\
\hline
\end{tabular}

\footnotetext{
${ }^{1}$ Tenderness (1 - extremely tough, 8 - extremely tender), Connective tissue amount (1 - abundant, 8 - no connective tissue), Juiciness ( 1 - extremely dry, 8 - extremely juicy), Off-flavor intensity ( 1 - trace amount, 8 - very extreme).

${ }^{2}$ Wet distillers grains plus solubles (\%, DM basis).

${ }^{a, b, c}$ Means in the same row having different superscripts are significant at $P \leq 0.05$ level.
} 
Downloaded from jas.fass.org at University of Nebraska-Lincoln Libraries on August 3, 2012 
Table 7. Least square means of minerals ( $\mathrm{mg} / \mathrm{kg}$ ) for strip loin, tenderloin, and top blade steaks from steers fed wet distillers grains plus solubles (WDGS) finishing diets.

\begin{tabular}{|c|c|c|c|c|c|c|}
\hline \multirow[t]{2}{*}{ Muscle } & \multirow[t]{2}{*}{ Min. $^{1}$} & \multicolumn{3}{|c|}{ Dietary treatments $^{2}$} & \multirow[b]{2}{*}{ S.E. ${ }^{3}$} & \multirow[b]{2}{*}{$P$-value } \\
\hline & & 0 & 15 & 30 & & \\
\hline \multicolumn{7}{|c|}{$\begin{array}{l}\text { Strip loin (Longissimus lumborum) } \\
\end{array}$} \\
\hline & $\mathrm{Ca}$ & 268 & 219 & 253 & 26 & 0.37 \\
\hline & $P$ & 2092 & 2048 & 2093 & 27 & 0.35 \\
\hline & K & 3586 & 3480 & 3576 & 47 & 0.18 \\
\hline & $M g$ & 232 & 227 & 230 & 5 & 0.77 \\
\hline & $S$ & 2061 & 2137 & 2142 & 94 & 0.77 \\
\hline & $\mathrm{Na}$ & 498 & 493 & 487 & 10 & 0.69 \\
\hline & $Z n$ & 41 & 42 & 40 & 1 & 0.40 \\
\hline & $\mathrm{Fe}$ & 18 & 16 & 17 & 1.7 & 0.75 \\
\hline & $M n$ & 5 & 3 & 4 & 0.9 & 0.28 \\
\hline & $\mathrm{Cu}$ & 1.2 & 1 & 1.1 & 0.09 & 0.42 \\
\hline \multicolumn{7}{|c|}{ Tenderloin (Poas major) } \\
\hline & $\mathrm{Ca}$ & 160 & 195 & 213 & 34 & 0.51 \\
\hline & $P$ & 2045 & 2041 & 2038 & 28 & 0.98 \\
\hline & K & 3363 & 3270 & 3312 & 46 & 0.40 \\
\hline & $M g$ & 240 & 241 & 240 & 4 & 0.97 \\
\hline & $S$ & $1890^{\mathrm{a}}$ & $1924^{\mathrm{a}}$ & $1574^{\mathrm{b}}$ & 112 & 0.05 \\
\hline & $\mathrm{Na}$ & 498 & 474 & 478 & 8 & 0.09 \\
\hline & $Z n$ & 34 & 36 & 34 & 1 & 0.22 \\
\hline & $\mathrm{Fe}$ & 25 & 22 & 21 & 1 & 0.11 \\
\hline & $M n$ & 4 & 2 & 3 & 0.7 & 0.27 \\
\hline & $\mathrm{Cu}$ & 1.2 & 1.4 & 1.4 & 0.1 & 0.50 \\
\hline \multicolumn{7}{|c|}{ Top blade (Infraspinatus) } \\
\hline & $\mathrm{Ca}$ & 417 & 466 & 364 & 56 & 0.44 \\
\hline & $P$ & 1814 & 1804 & 1816 & 19 & 0.89 \\
\hline & K & 2924 & 2867 & 2905 & 33 & 0.44 \\
\hline & $M g$ & 207 & 209 & 204 & 4 & 0.61 \\
\hline & $S$ & 1780 & 1689 & 1797 & 100 & 0.70 \\
\hline & $\mathrm{Na}$ & 679 & 656 & 687 & 12 & 0.18 \\
\hline & $Z n$ & 65 & 69 & 68 & 1 & 0.08 \\
\hline & $\mathrm{Fe}$ & 23 & 23 & 23 & 0.8 & 0.96 \\
\hline & $M n$ & 4 & 2 & 3 & 1 & 0.31 \\
\hline & $\mathrm{Cu}$ & 1.4 & 1.4 & 1.5 & 0.1 & 0.52 \\
\hline
\end{tabular}

\footnotetext{
${ }^{1}$ Minerals quantified

${ }^{2}$ Wet distillers grains plus solubles (\%, DM basis).

${ }^{3}$ Standard error

${ }^{\mathrm{a}, \mathrm{b}}$ Means in the same row having different superscripts are significant at $P \leq 0.05$ level.
} 
Table 8. Least square means of TBA values (mg malonaldehyde/kg) for top blade and strip loin steaks from steers fed wet distillers grains plus solubles finishing diets.

\begin{tabular}{|c|c|c|c|c|c|c|c|}
\hline \multirow{3}{*}{$\begin{array}{l}\text { Muscle } \\
\text { Top blade (Infraspinatus) }\end{array}$} & \multirow[b]{2}{*}{ day } & \multicolumn{3}{|c|}{ Dietary treatments $^{1}$} & \multirow[b]{2}{*}{$P$-value } & \multirow{2}{*}{\multicolumn{2}{|c|}{ Effects }} \\
\hline & & 0 & 15 & 30 & & & \\
\hline & & & & & $<0.01$ & linear & quadratic \\
\hline \multirow{7}{*}{ Strip loin (Longissimus lumborum) } & 0 & $0.68^{\mathrm{a}}$ & $0.53^{\mathrm{a}}$ & $0.59^{\mathrm{a}}$ & \multirow{7}{*}{$<0.01$} & 0.50 & 0.39 \\
\hline & 3 & $1.43^{\mathrm{Aa}}$ & $2.37^{\mathrm{ABb}}$ & $3.42^{\mathrm{Bb}}$ & & $<0.01$ & 0.53 \\
\hline & 7 & $3.84^{\mathrm{Ab}}$ & $5.04^{\mathrm{Ac}}$ & $8.42^{\mathrm{Bc}}$ & & 0.02 & 0.55 \\
\hline & & & & & & & \\
\hline & 0 & $0.58^{\mathrm{a}}$ & $0.52^{\mathrm{a}}$ & $0.45^{\mathrm{a}}$ & & 0.43 & 0.44 \\
\hline & 3 & $0.65^{\mathrm{a}}$ & $1.74^{\mathrm{a}}$ & $1.45^{\mathrm{a}}$ & & 0.12 & 0.26 \\
\hline & 7 & $2.02^{\mathrm{Ab}}$ & $3.77^{\mathrm{Bb}}$ & $4.80^{\mathrm{Bb}}$ & & 0.02 & 0.86 \\
\hline
\end{tabular}

${ }^{1}$ Wet distillers grains plus solubles (\%, DM basis).
A,B Means in the same row having different superscripts are significant at $P \leq 0.05$ level.
${ }^{\text {a,b,c }}$ Means in the same column having different superscripts are significant at $P \leq 0.05$ level. 


\section{Figure Caption}

Figure 1. The relationship between fat $\%$ and marbling score for cattle fed varying levels of wet distillers grains plus solubles (WDGS). 


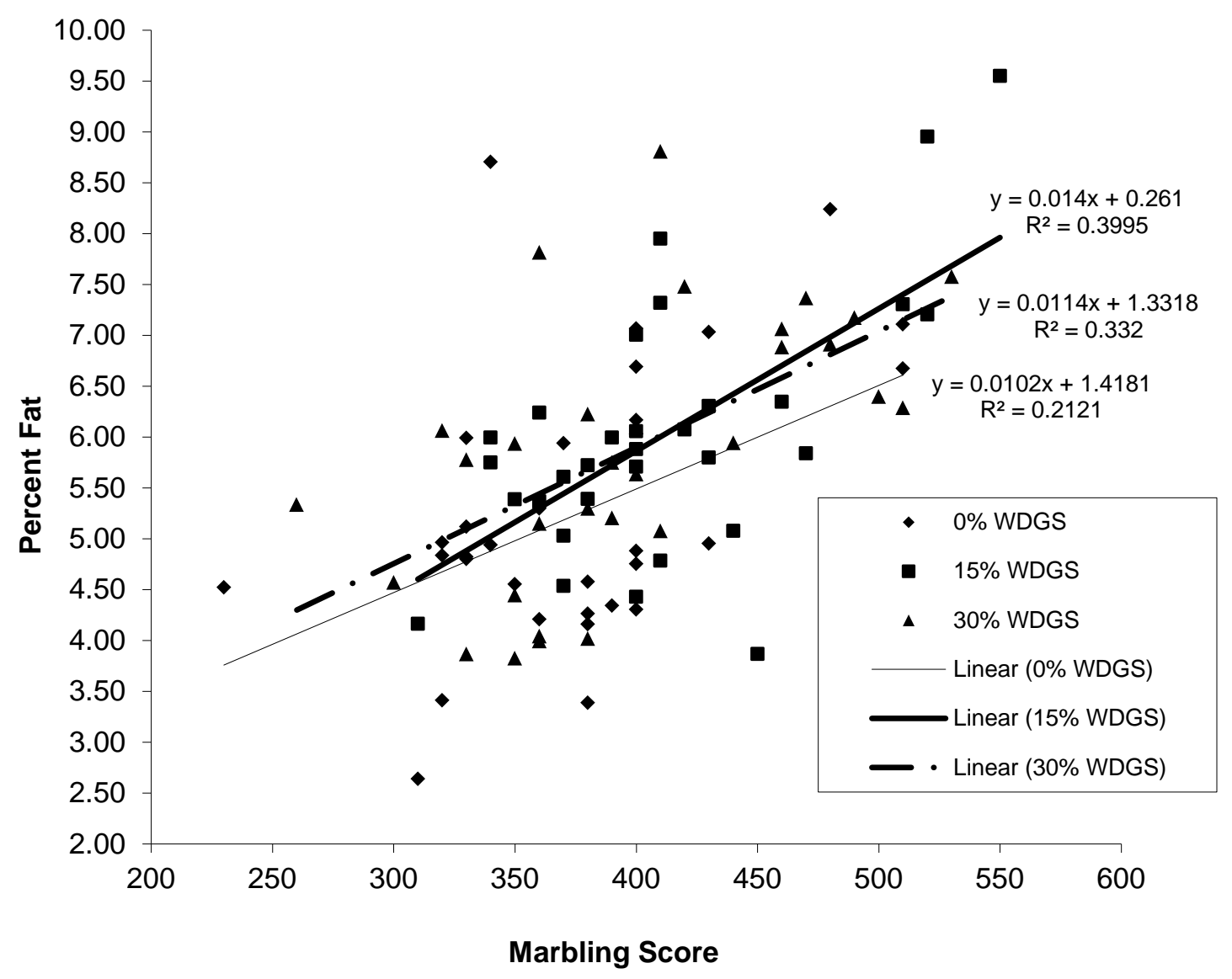

Figure 1. 


\section{Figure Caption}

Figure 2. Objective redness ( $a^{*}$ ) of strip loin (2a), tenderloin (2b), and top blade (2c) steaks from calffed steers fed 0, 15, and 30\% WDGS (DM Basis) displayed for $7 \mathrm{~d}$ under retail conditions. 


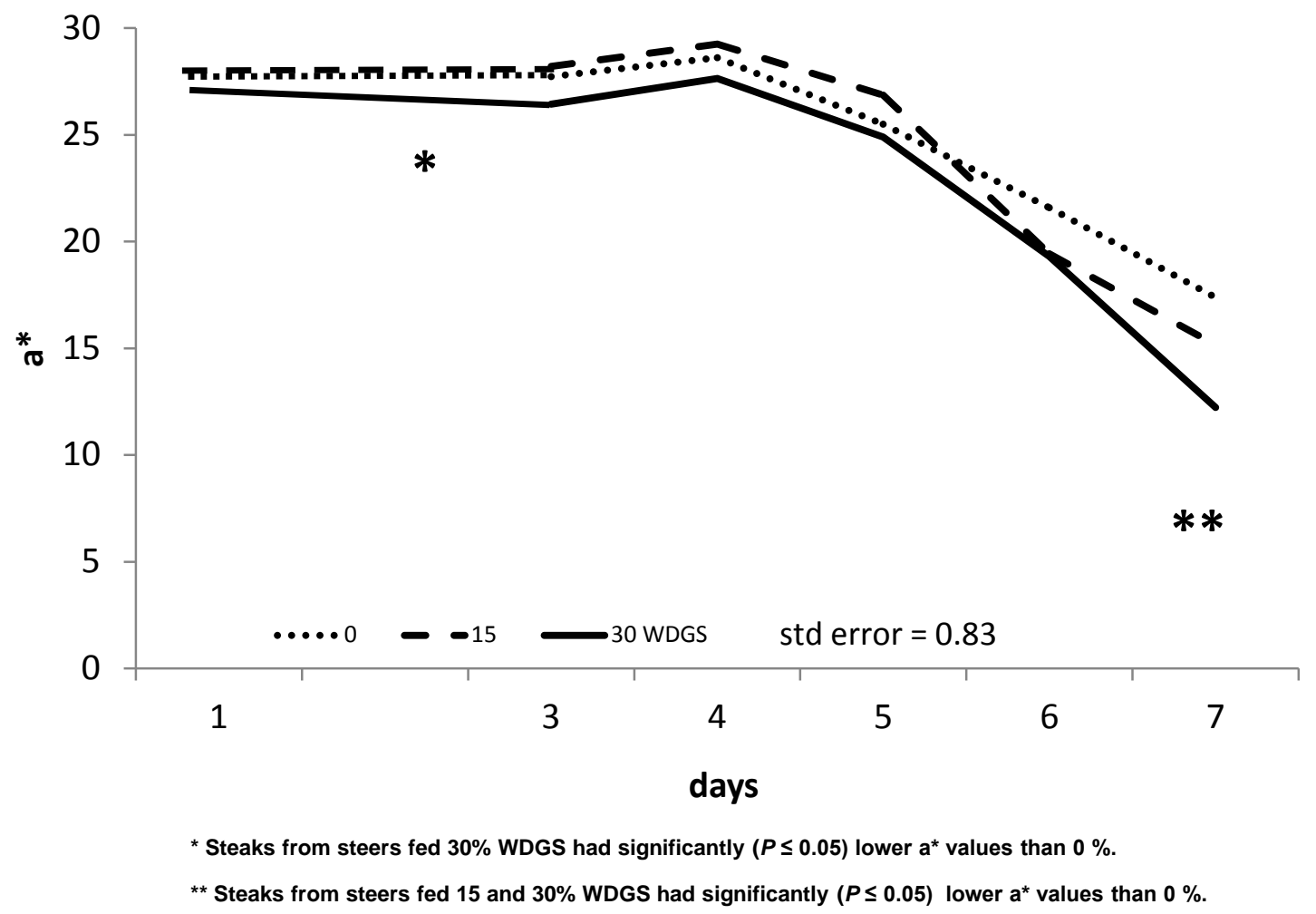

Figure 2a 


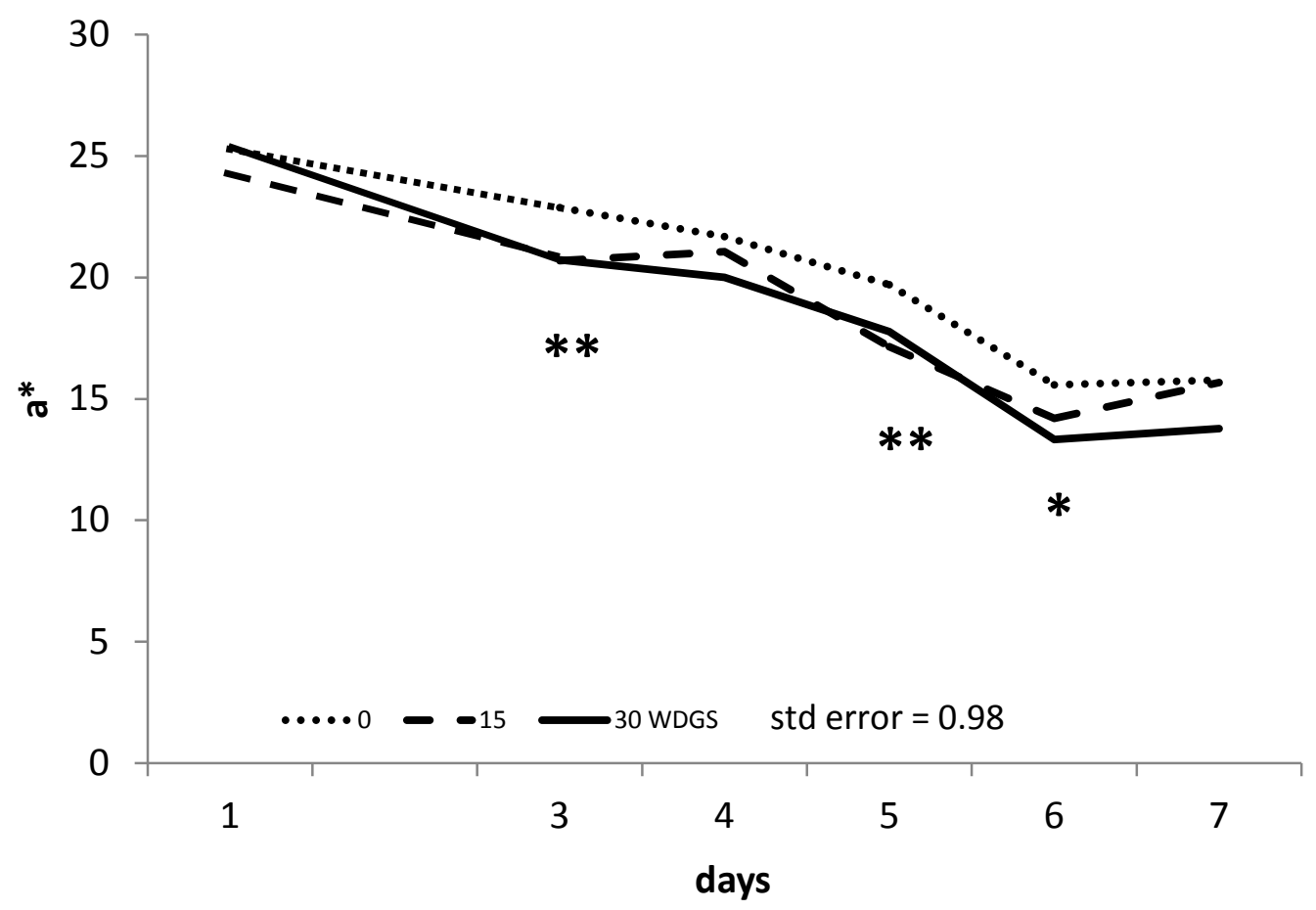

* Steaks from steers fed $30 \%$ WDGS had significantly $(P \leq 0.05)$ lower $a^{*}$ values than $0 \%$.

** Steaks from steers fed 15 and $30 \%$ WDGS had significantly $(P \leq 0.05)$ lower $a^{*}$ values than $0 \%$. 
Figure 2b

Downloaded from jas.fass.org at University of Nebraska-Lincoln Libraries on August 3, 2012 


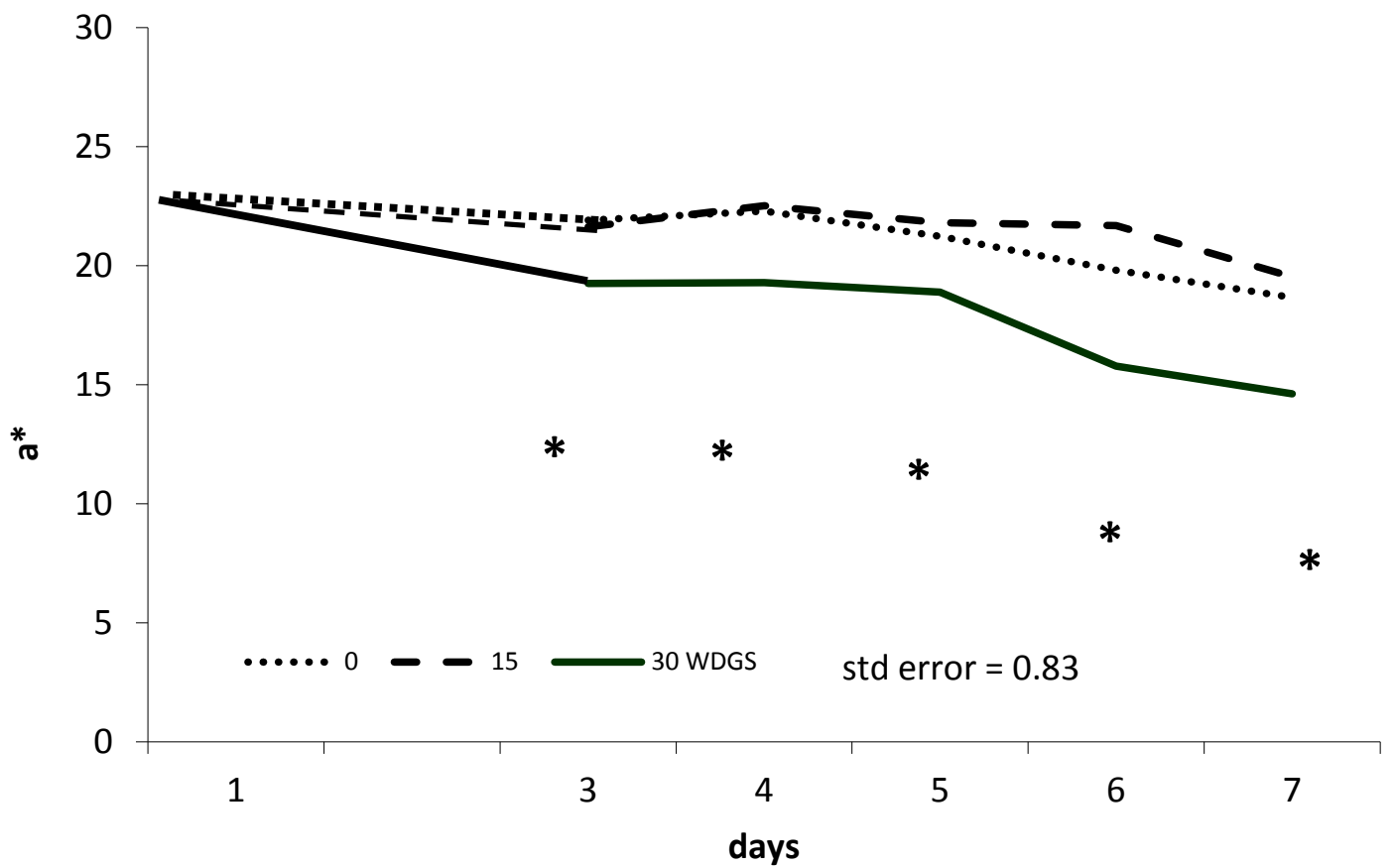

* Steaks from steers fed $30 \%$ WDGS had significantly $(P \leq 0.05)$ lower a* values than 0 and $15 \%$.

Figure 2c 